\title{
Managing pH of Organic Matrices and New Commercial Substrates for Ornamental Plant Production: A Methodological Approach
}

\author{
Sonia Cacini $^{1}(\mathbb{D})$, Sara Di Lonardo ${ }^{2, *(\mathbb{D})}$, Simone Orsenigo ${ }^{3} \mathbb{D}$ and Daniele Massa ${ }^{1}$ (D) \\ 1 Research Centre for Vegetables and Ornamental Crops, Council for Agricultural Research and \\ Economics (CREA), Via dei Fiori 8, 51012 Pescia, Italy; sonia.cacini@crea.gov.it (S.C.); \\ daniele.massa@crea.gov.it (D.M.) \\ 2 Research Institute on Terrestrial Ecosystems-National Research Council (IRET-CNR), Via Madonna del Piano, \\ 50019 Sesto Fiorentino, Italy \\ 3 Department of Earth and Environmental Sciences, University of Pavia, Via S. Epifanio 14, 27100 Pavia, Italy; \\ simone.orsenigo@unipv.it \\ * Correspondence: sara.dilonardo@cnr.it
}

check for updates

Citation: Cacini, S.; Di Lonardo, S.; Orsenigo, S.; Massa, D. Managing pH of Organic Matrices and New

Commercial Substrates for Ornamental Plant Production: A Methodological Approach. Agronomy 2021, 11, 851. https://doi.org/ 10.3390/agronomy11050851

Academic Editor: Miguel Ángel Sánchez-Monedero

Received: 31 March 2021

Accepted: 23 April 2021

Published: 27 April 2021

Publisher's Note: MDPI stays neutral with regard to jurisdictional claims in published maps and institutional affiliations.

Copyright: (c) 2021 by the authors. Licensee MDPI, Basel, Switzerland. This article is an open access article distributed under the terms and conditions of the Creative Commons Attribution (CC BY) license (https:// creativecommons.org/licenses/by/ $4.0 /)$.
Abstract: Professional peat-free substrates for ornamental plant production are increasingly required by nursery growers. Most promising materials are green compost, coconut coir dust, and woody fibre, used alone or in mixtures. One of the major concerns is $\mathrm{pH}$, usually higher than optimal. In this work, a method based on a three-step procedure was adopted to acidify three organic matrices alone or in mixtures and to individuate the most suitable product, between iron(II) sulphate 7-hydrate and elemental sulphur chips. Firstly, the determination of the buffering capacity by dilution with sulphuric acid was carried out to determine dosages. Afterwards, an incubation trial of 84 (iron(II) sulphate) or 120 days (sulphur chips) was conducted on matrices and substrate mixtures with calculated doses in a climatic chamber maintained at $21^{\circ} \mathrm{C}$. Iron(II) sulphate resulted not suitable because it caused a rapid, but not lasting, $\mathrm{pH}$ lowering and an excessive electrical conductivity (EC) increase. Sulphur chips could instead guarantee an adequate and lasting $\mathrm{pH}$ lowering. These results were then validated in the open field trial on matrices and substrates. The proposed acidification methodology could be considered in developing new substrates, but the rapidity of $\mathrm{pH}$ acidification and EC increase on plant and mineral nutrition should be further investigated.

Keywords: peat replacement; elemental sulphur chips; iron(II) sulphate; green compost; coconut coir dust; stabilized wood fibre; organic substrates; $\mathrm{pH}$; EC

\section{Introduction}

The valorization of organic waste in ornamental growing media has been recently grown in order to replace peat-based substrates in this sector [1]. In particular, the use of by-products, such as green compost, coconut coir dust, and woody fibre, is a widespread promising approach to reduce the use of peat in plant nurseries [2-7]. For this purpose, both physical and chemical characteristics of the matrices have to be deeply studied to allow the exploitation of new mixtures and a regular and optimal development of healthy plants on alternative peat-free substrates [8-12]. In general, some organic matrices show physical and chemical properties similar to peat, making them suitable as peat substitutes. Nevertheless, most of them cannot be used directly as container media or in mix due to their high $\mathrm{pH}$, above the desirable range [13-15]. When matrices or substrates have a higher than optimal $\mathrm{pH}$, for use as growing medium, plants can show Fe [16] or other deficiency symptoms (e.g., $\mathrm{P}, \mathrm{Mn}, \mathrm{B}$ ) since alkaline $\mathrm{pH}$ affects unfavorably nutrient availability to plants [1,17]. Thus, high $\mathrm{pH}$ represents a critical limiting factor, particularly in nursery production. To optimize matrices or substrates for better fit with nursery cultivation and management, a chemical treatment/correction must be applied. The feasibility for reducing 
the $\mathrm{pH}$ of materials to a level that falls in the optimal $\mathrm{pH}$ range depends on the $\mathrm{pH}$ buffering capacity of these materials [18]. Buffering of $\mathrm{pH}$ in materials used in growing media can be determined by two processes, namely the carbonate buffer and the $\mathrm{pH}$-dependent buffering capacity of carboxylic acid and the phenolic acid functional groups [18]. The $\mathrm{pH}$ modification and correction could be easily performed by nurseries in fertirrigation, when available. Nonetheless, in nurseries there is often no way to perform fertirrigation and correct the water $\mathrm{pH}$, thus limiting the use of new matrices and substrates that have to be chemically handled. For this purpose, standardized methodology is required also in absence of these facilities.

Acidification with elemental $S\left(S^{0}\right)$ is an efficient strategy for composts $[15,19,20]$ and organic material-based growing media $[16,21]$ to avoid nutritional deficiencies, due to excessively high $\mathrm{pH}$. The acidification is caused by the oxidation of $S^{0}$ to sulphuric acid from autotrophic bacteria (e.g., Thiobacillus sp.) and heterotrophic bacteria and fungi $[15,20,22]$, then the sulphuric acid combines with carbonate materials. After all carbonates have been dissolved, the sulphuric acid reacts with cations on the colloid surfaces [23], further decreasing the $\mathrm{pH}$ of the material. The rate of sulphur oxidation has been related to a wide number of factors, such as temperature, moisture, particle size of $\mathrm{S}$, aeration, and microbial biomass $[19,22,24,25]$. In the case of compost, it could be also related to the initial $\mathrm{pH}$ and carbonate content and the intended decrease in $\mathrm{pH}$, with higher doses needed for composts with a higher buffer capacity and a greater intended decrease in $\mathrm{pH}$ [26]. Costello and Sullivan [18] successfully acidified a wide range of composts by adding $S^{0}$ in a laboratory test. Moreover, recently the effect of storage, blending with an acidic management residue from nature conservation $[27,28]$, acidification with elemental S, and sieving out the finer fraction on characteristics of composts [26] have also been tested. Then, the effect of composts acidified using $\mathrm{S}^{0}$ on ornamentals has mostly been validated on compost and compost-based media during or after the acidification process, without negative effects on plant growth [16,21]. All these studies have been performed only with $S^{0}$ mainly in controlled conditions on one matrix (i.e., compost) to improve its quality.

The aim of this work was to test the effect of acidification with iron(II) sulphate 7-hydrate and elemental sulphur chips on three possible organic matrices for nursery growing media, such as green compost, coconut coir dust, and woody fibre, and substrate mixture prepared by their combination. A method based on a three-step procedure was adopted to individuate the best-performing product, among iron(II), sulphate 7-hydrate and elemental sulphur chips, and the optimal dosage to acidify these matrices. In the first step, the determination of the buffering capacity by dilution with sulphuric acid was carried out to determine the possible dosages. Afterwards, an incubation trial of 120 days, in a climatic chamber maintained constantly to $21^{\circ} \mathrm{C}$, has been performed on both matrices and growing media with the appropriate doses of acidifying chemicals and verify the buffering calculations and their results. Finally, an open-field experiment without plants was conducted to establish the accuracy of trial results and to understand if field performances were in line with the determination of buffering capacity and the incubation trials.

\section{Materials and Methods}

\subsection{Tested Matrices and Growing Media}

In this work, both three different organic matrices and three growing media, suitable for nursery ornamental plant production, already assessed in other previous studies [7], were tested. Briefly, the selected organic matrices, all provided by Terflor S.r.l (Capriolo, BS, Italy), were: (i) green compost, selected green wastes composted for 9 months; (ii) coconut coir dust, $75 \%$ dust and $25 \%$ short fibre; and (iii) stabilized wood fibre, $60 \%$ deciduous broad-leaf trees and $40 \%$ conifers. On the other hand, the three peat-free tested growing media, all based on the previous described matrices and developed in a previous study [7], were: (i) coconut coir dust:pumice $70: 30 \mathrm{v} \mathrm{v}^{-1}$ (CP); (ii) coconut coir dust:green 
compost 55:45 $\mathrm{v} \mathrm{v}^{-1}$ (CGC); (iii) coconut coir dust:green compost:stabilized wood fibre 40:30:30 v v ${ }^{-1}$ (CGCW).

Physical and chemical characteristics of these organic byproducts and growing media were analyzed. Water holding capacity ( $\mathrm{W}-1 \mathrm{kPa} \%)$, available water capacity (AWC), bulk density (BD), and total porosity (TP) were determined according to De Boodt and Verdonck method ([29]; data not shown). Baseline values of $\mathrm{pH}$ and electrical conductivity (EC) of both matrices and growing media are shown in Table 1, while all other chemical characteristics of organic matrices are shown in Table S1. Total N and C content were determined on a dry matter basis (EN 13654-1/2001 and EN13137/2002, respectively); pH (EN 13037/1999), EC (EN 13038/1999), and cation exchange capacity (CEC) [30] were analyzed after a water extraction; $\mathrm{P}-\mathrm{PO}_{4}, \mathrm{~K}_{2} \mathrm{O}, \mathrm{Ca}, \mathrm{Mg}, \mathrm{Na}, \mathrm{Fe}, \mathrm{Mn}, \mathrm{Cu}, \mathrm{Zn}, \mathrm{B}, \mathrm{Cl}, \mathrm{Cd}, \mathrm{Cr}, \mathrm{Ni}$, $\mathrm{Pb}$, and $\mathrm{Hg}$ were analyzed following EN 13652/2001, after a wet digestion $\mathrm{HNO}_{3}: \mathrm{HClO}_{4}$ $5: 2 \mathrm{v} \mathrm{v}^{-1}$ at $230{ }^{\circ} \mathrm{C}$ for $1 \mathrm{~h}$. Finally, for the green compost also microbiological parameters were analyzed, as requested by the Italian and EU Regulations (Italian Legislative Decree n. 75 29/04/2010, and Regulation (EC) No 2003/2003).

Table 1. Baseline values of $\mathrm{pH}$ and electrical conductivity (EC) of both tested matrices and growing media. CP: coconut coir dust:pumice, CGC: coconut coir dust:green compost, CGCW: coconut coir dust:green compost:stabilized wood fibre, CE: electrical conductivity. Values represent mean \pm standard deviation calculated of three replicates.

\begin{tabular}{cccc}
\hline Organic Matrices & Green Compost & Coconut Coir Dust & Stabilized Wood Fibre \\
\hline $\mathrm{pH}$ & $8.02 \pm 0.09$ & $7.70 \pm 0.03$ & $7.26 \pm 0.11$ \\
$\mathrm{EC}\left(\mu \mathrm{S} \mathrm{cm}{ }^{-1}\right)$ & $596.00 \pm 74.72$ & $171.80 \pm 6.41$ & $175.80 \pm 21.69$ \\
\hline Growing media & $\mathrm{CP}$ & $\mathrm{CGC}$ & $\mathrm{CGCW}$ \\
\hline $\mathrm{pH}$ & $7.68 \pm 0.09$ & $8.48 \pm 0.06$ & $8.08 \pm 0.12$ \\
$\mathrm{EC}\left(\mu \mathrm{S} \mathrm{cm}^{-1}\right)$ & $136.67 \pm 26.81$ & $394.00 \pm 13.70$ & $343.30 \pm 86.20$ \\
\hline
\end{tabular}

\subsection{Titration Curve and Theoretical Buffering Capacity Trials}

An equivalent of $5 \mathrm{~g}$ dry weight of each moist matrix and growing media was added to $100 \mathrm{~mL}$ cups. Since the goal of the experiment was to evaluate the applicability of the $\mathrm{pH}$ buffering capacity determination method and the chemical analysis of green compost, as well as growing media containing compost (i.e., CGC and CGCW), confirmed higher $\mathrm{pH}$ and $\mathrm{EC}$ values in comparison with the other two matrices and the $\mathrm{CP}$ growing media, two different series of $\mathrm{H}_{2} \mathrm{SO}_{4}$ dilutions were used: (i) $0,0.5,0.75,1,2,3$, or $4 \mathrm{~mL}$ of $0.25 \mathrm{M}$ $\mathrm{H}_{2} \mathrm{SO}_{4}$ for coconut coir dust and stabilized wood fibre and (ii) $0,1,2,3,4,7$, or $10 \mathrm{~mL}$ of $0.25 \mathrm{M} \mathrm{H}_{2} \mathrm{SO}_{4}$ for green compost and all tested growing media, added with distilled water sufficient to bring total liquid addition to $50 \mathrm{~mL}$, thereby maintaining a fixed 1:10 dry matrix to water ratio. Samples were stirred with a spoon for $10 \mathrm{~s}$ after acid addition (TOh), and then kept at a constant temperature of $21^{\circ} \mathrm{C}$ and stirred again for another $10 \mathrm{~s}$ immediately prior to measuring both $\mathrm{pH}$ and EC at 72 and $144 \mathrm{~h}$ (T72h and T144h, respectively). The theoretical buffering capacity (BC; calculated from the titration curve), namely the quantity of acidity or $\mathrm{H}^{+}$needed to reduce $\mathrm{pH}$ by one unit, was calculated as described by Costello and Sullivan [18] for compost buffering capacity:

$$
\mathrm{BC}=-(1 / \text { slope })
$$

where $\mathrm{BC}=$ Buffering Capacity $\left(\mathrm{mol} \mathrm{H} \mathrm{H}^{+} \mathrm{kg}\right.$ matrix $/ \mathrm{pH}$ unit $)$; slope $=$ fitted slope of linear regression line for each matrix.

\subsection{Acidification Trials in Climatic Chamber and in Open Filed Conditions}

A first acidification experiment was performed by using commercial iron(II) sulphate $\left(\mathrm{FeSO}_{4} \cdot 7 \mathrm{H}_{2} \mathrm{O}, 99 \% \mathrm{w} \mathrm{w}{ }^{-1}\right.$ purity; Agribios Italiana S.r.l., Limena, $\mathrm{PD}$, Italy) and elemental sulphur chips $\left(\mathrm{S}^{0}, 98.5 \% \mathrm{w} \mathrm{w}^{-1}\right.$ purity, particle diameter $0-6 \mathrm{~mm}$; Solfochimica S.r.l., 
Realmonte, AG, Italy). They were mixed with each matrix sample at a rate determined with BC to achieve 0 (control), 1, and 1.5 units of acidification for coconut coir dust and stabilized wood fibre and 0 (control), 1, and 2 units of acidification for compost, in three replications (18 pots per replicate). The elemental sulphur chips $S^{0}$ and iron(II) sulphate addition rate required to reach target $\mathrm{pH}$ was calculated by modifying and readapting Costello and Sullivan's equation [18]:

Addition rate of $\mathrm{S}^{0}$ or $\mathrm{FeSO}_{4} \cdot 7 \mathrm{H}_{2} \mathrm{O}\left(\mathrm{g} \mathrm{kg}^{-1}\right.$ to reach target $\left.\mathrm{pH}\right)=$ number of unit $\mathrm{pH}$ change $\times \mathrm{BC} \times \mathrm{S}_{\mathrm{eq}} \times 1 / \mathrm{S}_{\mathrm{eff}}$

where number of unit $\mathrm{pH}$ change $=1$, or 1.5 , or $2 ; \mathrm{S}_{\mathrm{eq}}=$ equivalent weight of $\mathrm{FeSO}_{4} \cdot 7 \mathrm{H}_{2} \mathrm{O}$ $\left(278 \mathrm{~g} \mathrm{~mol}^{-1} \mathrm{H}^{+}\right)$or $\mathrm{S}^{0}\left(16 \mathrm{~g} \mathrm{~mol}^{-1} \mathrm{H}^{+}\right)$; $\mathrm{S}_{\text {eff }}=$ oxidation efficiency of $\mathrm{FeSO}_{4} \cdot 7 \mathrm{H}_{2} \mathrm{O}(=0.3)$ or $S^{0}(=0.7)$, values chosen in function of products characteristics and particle size [18].

Plastic pots $(14 \mathrm{~cm} \varnothing ; 1.8 \mathrm{~L})$ with drainage holes were filled with the amended matrices, moistened at container capacity, closed in bags, and then incubated at $21^{\circ} \mathrm{C}$ for 120 days. $\mathrm{pH}$ and EC of potting mixes were determined in a suspension $(\mathrm{pH})$ or extract (EC) by using the 1:5 $\left(\mathrm{v} \mathrm{v}^{-1}\right)$ water extraction procedure (EN 13037 1999; EN 13038 1999) at selected intervals, or rather at day 0 (T0), 14 (T14), 28 (T28), 42 (T42), 84 (T84), and 120 (T120; where T120 corresponded to $\mathrm{pH}$ stabilization [18]). Moreover, a similar trial on the three chosen growing media was performed by maintaining the same conditions but adding only elemental sulphur chips to achieve 0 (control), 1, and 2 units of acidification.

Finally, a third experiment was conducted in operative open-field condition at CREA Research Centre for Vegetable and Ornamental Crops (Pescia, Tuscany, Italy; lat. $43^{\circ} 54^{\prime} \mathrm{N}$, long. $10^{\circ} 42^{\prime} \mathrm{E}$, altitude $\left.62 \mathrm{~m}\right)$, in the same plastic pot type $(14 \mathrm{~cm} \varnothing ; 1.8 \mathrm{~L})$ of previous described trial, without plants, by adding elemental sulphur chips to achieve 0 (control), 1 , and 1.5 units of acidification for $C$ and $W$, and 0 (control), 1, and 2 units of acidification for GC and growing media, in three replications (12 pots per replicate). Irrigation was applied by capillary drip irrigation managed by timer basing on weather conditions simulating crop condition (water irrigation $\mathrm{pH}$ and EC values were on average 6.9 and $0.41 \mathrm{dS} \mathrm{m}^{-1}$, respectively). $\mathrm{pH}$ and EC values were evaluated at day 0 (T0), 42 (T42), 84 (T84), and 120 (T120). This last trial was conducted in summer season for 120 days (from 6 June to 4 October 2018). In this period temperature varied between $12.6^{\circ} \mathrm{C}$ and $34.1^{\circ} \mathrm{C}$ (average value on the whole period was $23.24{ }^{\circ} \mathrm{C}$ ), relative humidity ranged between $30 \%$ and $80 \%$ (average value 58.5\%), and total rain was $121 \mathrm{~mm}$.

\subsection{Statistical Analysis}

Two-way analysis of variance (ANOVA) was performed to assess the effect of each treatment on $\mathrm{pH}$ with respect to sampled day. Treatments were then compared by Tukey's multiple comparisons test. One-way analysis of variance (ANOVA) was instead performed to assess the effect of each treatment on EC respect to selected intervals. Treatments were then compared by Tukey test (HSD). Statistical and graphic analysis were supported by Statgraphics Centurion XV (Statpoint Technologies, Inc., Warrenton, VA, USA) Prism 6 (GraphPad Software, Inc., La Jolla, CA, USA) software.

\section{Results and Discussion}

\subsection{Titration Curve and Theoretical Buffering Capacity Tests}

All matrix and growing media had a $\mathrm{pH}$ equal or greater than 6.5 (Table 1) thus requiring acidification to meet specifications for plant nursery (i.e., $\mathrm{pH}$ 5.5-6.5). Green compost, as well as growing media containing compost, reported higher $\mathrm{pH}$ and EC values compared with coconut coir dust and stabilized wood fibre (Table 1). Lowering the $\mathrm{pH}$ of these matrices used as growing media or as growing media constituents for containerized crop production needed the specific titration curve of the material. From this titration curve, the amount of amendment required to reach an acceptable/optimum $\mathrm{pH}$ could be accurately determined (i.e., for different kind of waste derived compost [15,16,20,21,31-34]). 
Although in previous works $\mathrm{pH}$ adjustment trials were conducted on different organic matrices beside compost [21], for the first time this method was applied to matrices, such as coconut coir dust and stabilized wood fibre and to mixed growing media. Responses to acid addition were described for all matrices and substrates by a linear function, and these results were similar to those obtained by other authors for compost [18]. The $\mathrm{pH}$ buffering capacity obtained for all the matrices and growing media are presented in Figure 1 together with the regression equations and their coefficients of determination $\left(\mathrm{r}^{2}\right)$. The slope of the linear regression between the $\mathrm{pH}$ of the matrix and the amount of sulphuric acid added was not calculated after $144 \mathrm{~h}$ of incubation, but at $72 \mathrm{~h}$ because a plateau was already achieved at this time (data not shown). Stabilized wood fibre and coconut coir dust (Figure 1A) showed a steeper slope ( -9.3697 and -8.4018 , respectively) than that for green compost (-2.8462; Figure 1B), thus obtaining different and lower BC values $(0.107$ and 0.119 for stabilized wood fibre and coconut coir dust, respectively). In all matrices, the hydrogen ion requirements ( $\mathrm{m}_{\mathrm{eq}} \mathrm{H}^{+} \mathrm{L}^{-1}$ matrix) are inversely proportional to $\mathrm{pH}$ decrease. In particular, these different results indicated that $\mathrm{m}_{\mathrm{eq}} \mathrm{H}^{+} \mathrm{L}^{-1}$ matrix of stabilized wood fibre and coconut coir dust were lower than for compost to obtain an equivalent $\mathrm{pH}$ drop. This relatively minor amount of titratable hydrogen ions, required for stabilized wood fibre and coconut coir dust, was probably related to the lower buffer capacity (i.e., cation exchange capacity and exchangeable cations) of those materials compared with green compost. In any case, data obtained on green compost are consistent with those obtained by Costello and Sullivan [18] on different types of composted materials.
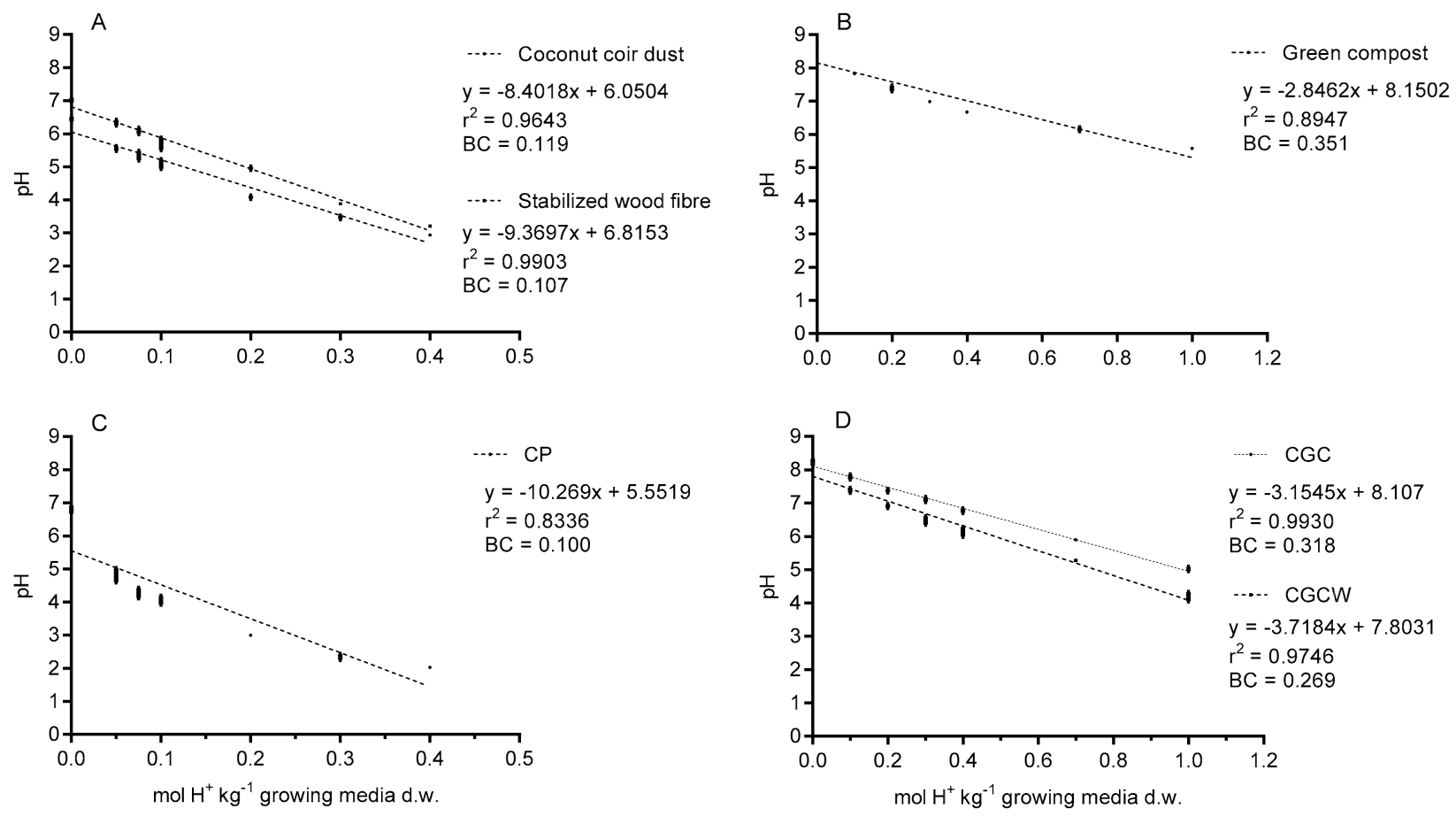

Figure 1. Determination of $\mathrm{pH}$ buffering capacity (BC) calculated as reported in Equation (1) and obtained at $72 \mathrm{~h}$ for: (A) coconut coir dust and woody fibre; (B) green compost; (C) coconut coir dust:pumice (CP); (D) coconut coir dust:green compost (CGC) and coconut coir dust:green compost:stabilized wood fibre (CGCW). d.w. is growing media dry weight. Values represent mean \pm standard deviation calculated on three replicates. The linear regression equation is significant for $p<0.001$.

A similar result was obtained for growing media (Figure 1C,D), where $\mathrm{CP}$ treatment showed a steeper slope $(-10.269)$ with respect to growing media containing green compost (i.e., CGC and CGCW; -3.1545 and -3.7184 , respectively). Accordingly, CGC (compost at $45 \%$ by volume) and CGCW ( $30 \%$ by volume) showed similar BC values (BC $=0.269$ and $B C=0.318$, respectively), slightly lower than green compost alone $(B C=0.351)$, as 
reported in Figure 1. If considering the composition of the growing media, green compost was the matrix that higher influenced their BC even when present in low (30\%) percentage in respect to the other matrices, probably due to its high BC. At the best of our knowledge, any studies are available on BC of growing media other than compost and peat.

\subsection{Acidification Trials}

The dose of sulphur amendment, required to reach $\mathrm{pH}$ lower of 1 point calculated from the titration curves, was $0.45,0.39$, and $5.60 \mathrm{~g}$ of elemental sulphur chips per litre matrix for coconut coir dust, stabilized wood fibre, and green compost, respectively. When using ferrous sulphate, the requirements for these matrices were 18.18, 15.93, and $226.95 \mathrm{~g}$ of iron(II) sulphate per litre matrix. To decrease $\mathrm{pH}$ more than 1 point (1.5 in the case of coconut coir dust and stabilized wood fibre; or 2 points in the case of compost), larger doses of sulphur $(0.67 \mathrm{~g}, 0.59 \mathrm{~g}$, and $5.6 \mathrm{~g}$ for coconut coir dust, stabilized wood fibre, and green compost, respectively) or ferrous sulphate $(27.28 \mathrm{~g}, 23.89 \mathrm{~g}$, and $226.95 \mathrm{~g}$ for coconut coir dust, stabilized wood fibre, and green compost, respectively) were needed. These results indicated that there is a need to specify and study each matrix singly to have a precise $\mathrm{pH}$ adjustment for each new or unknown material, as already stated for each type of composts by Carrión et al. [15] and Costello and Sullivan [18]. Moreover, data highlighted how the type of starting matrix influenced the buffering capacity also for those substrates that needed to be acidified by different doses of $S^{0}$. However, an acidifying process needs the knowledge, not only of the specific titration curve of each material, but also of the performance under field conditions [18,34,35]. For this reason, we carried out an incubation trial and an open field experimentation. Figure 2 shows the results relating to the incubation tests with the calculated doses of elemental sulphur chips for 120 days and with iron(II) sulphate for 84 days carried out with each matrix in a climatic chamber at $21^{\circ} \mathrm{C}$, and that related to growing media supplied with elemental sulphur for 84 days. All the treatments in climatic chamber (those with elemental sulphur chips and iron(II) sulphate) reached the final $\mathrm{pH}$ expected from the titration curves, in line with what Carrión et al. [15] and Costello and Sullivan [18] reported in their experiences on composts. Moreover, it was clear that the maximum effectiveness of elemental sulphur chips in the acidification process was 42 days from the start of treatment, while in the following period the $\mathrm{pH}$ values tended to rise gradually. In contrast to the $\mathrm{pH}$ patterns observed in the treatments, $\mathrm{pH}$ values measured throughout the experiment in the control treatment in both matrices and growing media, remained nearly invariable compared with measured baseline values (Table 1), except for coconut coir dust, where a significant reduction was observed after T42, probably because of its low BC (Figure 1).

Between the two types of tested sulphur, the only one that can be used "safely" for pot cultivation was elemental sulphur chips, while the use of iron(II) sulphate resulted as not suitable since it caused a sudden and excessive lowering of $\mathrm{pH}$, reaching very low values and in any case lower than those desired (Figure 1), as well as causing an excessive increase in the EC (Table 2) not appropriate for soilless plant cultivation, even directly at moment of supplying (T0) and maintaining this kind of trend during the trial, with values higher than $0.5 \mathrm{dS} \mathrm{m}^{-1}$, that is reported as the upper optimal values for growing media [36]. Electrical conductivity values higher than optimal were observed also in green compost treated with sulphur chips, as this matrix is characterized by a high baseline value (Table 1). Nevertheless, green compost is rarely use as a stand-alone growing media, but as a component [12,37]. These results on EC observed for composts related to both elemental sulphur and, especially, iron(II) sulphate, were in agreement with the previous studies of Carrion et al. [15]. 

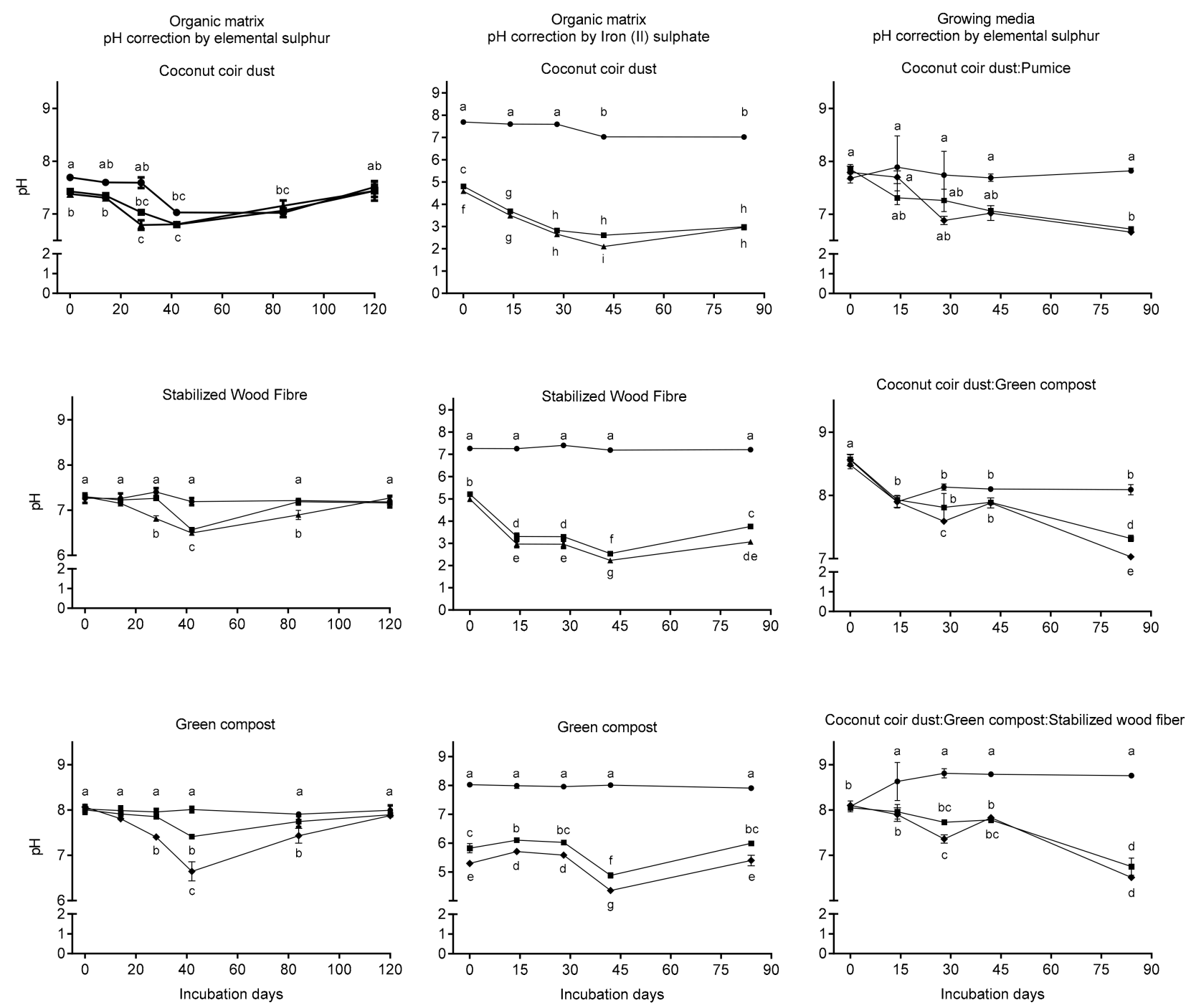

\section{Control}

- 1 point $\mathrm{pH}$ adjustment

-1.5 point $\mathrm{pH}$ adjustment

-2 point pH adjustment

\begin{tabular}{|c|c|c|c|}
\hline & $\begin{array}{c}\text { Elemental Sulphur } \\
\text { 0-120 Incubation Days }\end{array}$ & $\begin{array}{c}\text { Iron(II) Sulphate } \\
\text { 0-84 Incubation Days }\end{array}$ & $\begin{array}{l}\text { Elemental Sulphur } \\
\text { 0-84 Incubation Days }\end{array}$ \\
\hline & \multicolumn{2}{|c|}{ Coconut coir dust } & Coconut coir dust:pumice \\
\hline $\mathrm{pH}$ & $* * *$ & $* * *$ & $* * *$ \\
\hline Incubation days & $* * *$ & $* * *$ & $* * *$ \\
\hline \multirow[t]{2}{*}{$\mathrm{pH} \times$ Incubation days } & $* * *$ & $* * *$ & $* * *$ \\
\hline & \multicolumn{2}{|c|}{ Stabilized wood fibre } & $\begin{array}{c}\text { Coconut coir dust:green com- } \\
\text { post }\end{array}$ \\
\hline $\mathrm{pH}$ & $* * *$ & $* * *$ & *** \\
\hline Incubation days & $* * *$ & $* * *$ & $* * *$ \\
\hline \multirow[t]{2}{*}{$\mathrm{pH} \times$ Incubation days } & $* * *$ & $* * *$ & $* * *$ \\
\hline & \multicolumn{2}{|c|}{ Green compost } & $\begin{array}{l}\text { Coconut coir dust:green com- } \\
\text { post:stabilized wood fibre }\end{array}$ \\
\hline $\mathrm{pH}$ & $* * *$ & $* * *$ & $* * *$ \\
\hline Incubation days & $* * *$ & $* * *$ & $* * *$ \\
\hline $\mathrm{pH} \times$ incubation days & $* * *$ & $* * *$ & $* * *$ \\
\hline
\end{tabular}

Figure 2. $\mathrm{pH}$ trend of the different matrices (coconut coir dust, stabilized wood fibre, and green compost) and of the tested growing media during the incubation tests (i.e., climatic chamber) at constant temperature $\left(21^{\circ} \mathrm{C}\right)$ with elemental sulphur 
chips and iron(II) sulphate using the dosages calculated through the titration curve for lowering the $\mathrm{pH} .-1.5 \mathrm{pH}$ point adjustment is referred to coconut coir dust and stabilized wood fibre, while -2 point $\mathrm{pH}$ adjustment is referred to compost and growing media. Mean separation across time within each addition rate and across dosage at the same time was performed by two-way analysis of variance (ANOVA analysis in table: n.s., not significant; ${ }^{*} p \leq 0.05$; ${ }^{* *} p \leq 0.01$; ${ }^{* * *} p \leq 0.001$ ). Different letters indicate significantly different values (Tukey's multiple comparisons test). Each data point is the mean of three replicates \pm standard deviation.

Table 2. Electrical conductivity (EC) values obtained in the climatic chamber incubation trials at different time after sulphur addition (i.e., 0 days (T0), after 84 days (T84), and after 120 days (T120)) on the three tested organic matrices and for different dosages to reach different points of $\mathrm{pH}$ adjustment. Data referred to T14 (after 14 days), T28 (after 28 days), and T42 (after 42 days) are not shown. Values represent mean \pm standard deviation calculated of three replicates. ANOVA analysis: n.s. $=$ not significant; different letters for each treatment indicate significantly different values among days (HSD test, $p<0.05$ ).

\begin{tabular}{ccccc}
\hline & & \multicolumn{3}{c}{ Reached EC Values $\left(\boldsymbol{\mu S} \mathbf{~ c m}^{-1}\right)$} \\
\cline { 2 - 5 } & Point pH Adjustment & T0 & T84 & T120 \\
\hline Coconut coir & 0 (control) & $171.8 \pm 6.4 \mathrm{a}$ & $117.3 \pm 1.9 \mathrm{~b}$ & $126.1 \pm 4.3 \mathrm{ab}$ \\
dust & $-1 \mathrm{~S}_{0}$ & $146.6 \pm 8.3 \mathrm{a}$ & $124.3 \pm 4.0 \mathrm{a}$ & $162.7 \pm 2.7 \mathrm{~b}$ \\
& $-1.5 \mathrm{~S}_{0}$ & $151.6 \pm 6.0 \mathrm{ab}$ & $166.9 \pm 20.2 \mathrm{a}$ & $174.1 \pm 1.0 \mathrm{a}$ \\
& $-1 \mathrm{FeSO}_{4}$ & $2017.0 \pm 158.2 \mathrm{a}$ & $1523.7 \pm 26.6 \mathrm{~b}$ & - \\
& $-1.5 \mathrm{FeSO}_{4}$ & $2584.0 \pm 63.6 \mathrm{a}$ & $1986.7 \pm 93.1 \mathrm{~b}$ & - \\
\hline Stabilized & $0($ control) & $175.8 \pm 21.7 \mathrm{a}$ & $157.6 \pm 10.3 \mathrm{ab}$ & $124.3 \pm 4.7 \mathrm{~b}$ \\
Wood Fibre & $-1 \mathrm{~S}_{0}$ & $167.9 \pm 2.7$ & $187.9 \pm 28.2$ & $154.2 \pm 51.0$ \\
& $-1.5 \mathrm{~S}_{0}$ & $140.4 \pm 7.7 \mathrm{ab}$ & $162.6 \pm 10.3 \mathrm{a}$ & $103.6 \pm 6.0 \mathrm{~b}$ \\
& $-1 \mathrm{FeSO}_{4}$ & $1387.3 \pm 86.2 \mathrm{a}$ & $1133.7 \pm 80.5 \mathrm{ab}$ & - \\
\hline Green & $-1.5 \mathrm{FeSO}_{4}$ & $2243.3 \pm 56.3 \mathrm{a}$ & $1382.3 \pm 37.5 \mathrm{~b}$ & - \\
\hline Compost & $0($ control $)$ & $596.0 \pm 74.7 \mathrm{c}$ & $709.3 \pm 49.9 \mathrm{ab}$ & $758.3 \pm 68.6$ \\
& $-1 \mathrm{~S}_{0}$ & $697.0 \pm 102.5 \mathrm{c}$ & $945.3 \pm 58.5 \mathrm{~b}$ & $1310.3 \pm 114.2$ \\
& $-2 \mathrm{~S}_{0}$ & $1021.7 \pm 18.8 \mathrm{ab}$ & $1327.0 \pm 51.0 \mathrm{a}$ & $1024.0 \pm 252.6$ \\
& $-1 \mathrm{FeSO}_{4}$ & $4390.0 \pm 10.0 \mathrm{a}$ & $3367.3 \pm 84.0$ & - \\
\hline
\end{tabular}

For this reason, the incubation of matrices treated with iron(II) sulphate last at day 84 and not at day 120 and acidification trials on growing media and in open field condition were performed by adding only elemental sulphur (Figure 3). Also, in this case, the acidification caused by the oxidation of $S^{0}$ to sulphuric acid was mostly in line on what expected. It is a matter of fact that the rate of sulphur oxidation has been related to a wide number of factors, such as temperature, moisture, particle size of $S$, aeration, and microbial biomass $[19,22,24,25]$.

Contrarily to incubation trials, in open field conditions each control treatment, or rather without $S^{0}$ supply, showed a certain $\mathrm{pH}$ lowering, probably due to irrigation water characterized by $\mathrm{pH}$ values of 6.9 , especially when in presence of green compost and of baseline $\mathrm{pH}$ values higher than 8.0. In the case of coconut coir dust, stabilized wood fibre, and coconut coir dust:pumice, their its low BC values (Figure 1). The presence of irrigation water and rain (around $34 \mathrm{~mm}$ ) could contribute to the decrease of $\mathrm{pH}$ in the open field trials in the period T0-T42. Particularly, the substrate coconut coir dust:pumice resulted not affected by the application of the two dosages of $S^{0}$, both in climatic chamber (Figure 2), where a significant $\mathrm{pH}$ reduction was observed only at the end of the trial (T82), and, overall, in open field condition, where $\mathrm{S}^{0}$ addition did not influenced $\mathrm{pH}$ values (Figure 3). This behavior can be attributed to the recognized low microbial activity typical of coconut coir materials [38]. 
Treatments with $\mathrm{S}^{0}$ resulted as particularly effective on green compost, especially in open field condition, not only for its higher buffering capacity, but also thanks to its well-known high microbial activity with respect to others organic matrices [37,39], that is fundamental for the elemental $\mathrm{S}$ transformation in sulphate both in soil and organic material $[19,40]$.

$\mathrm{pH}$ correction by elemental sulphur
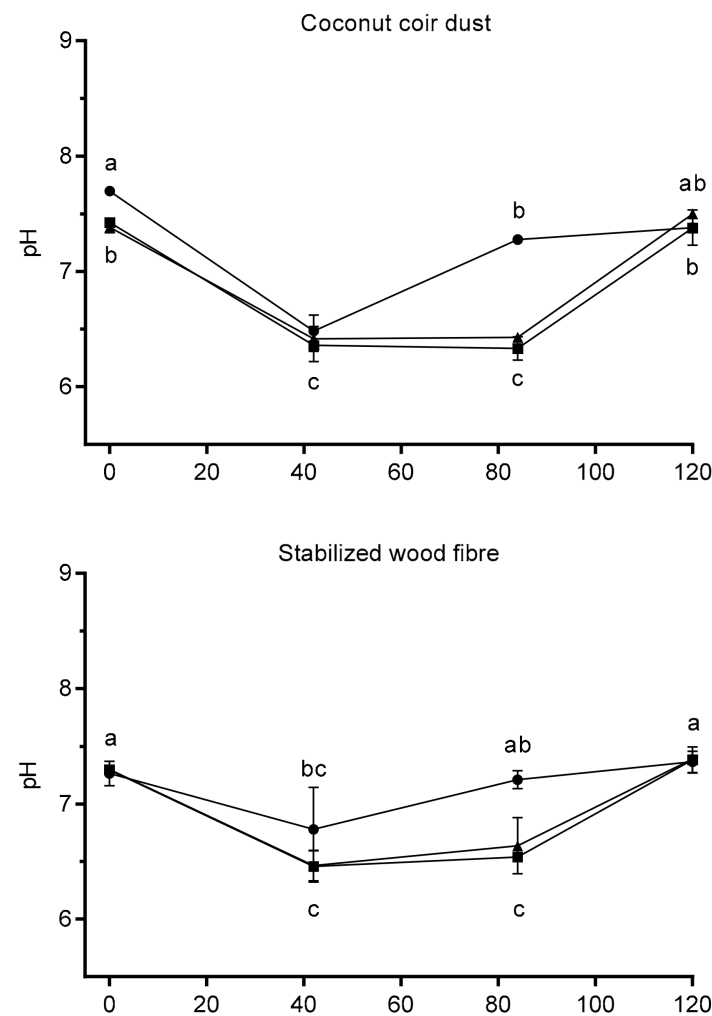

Green compost

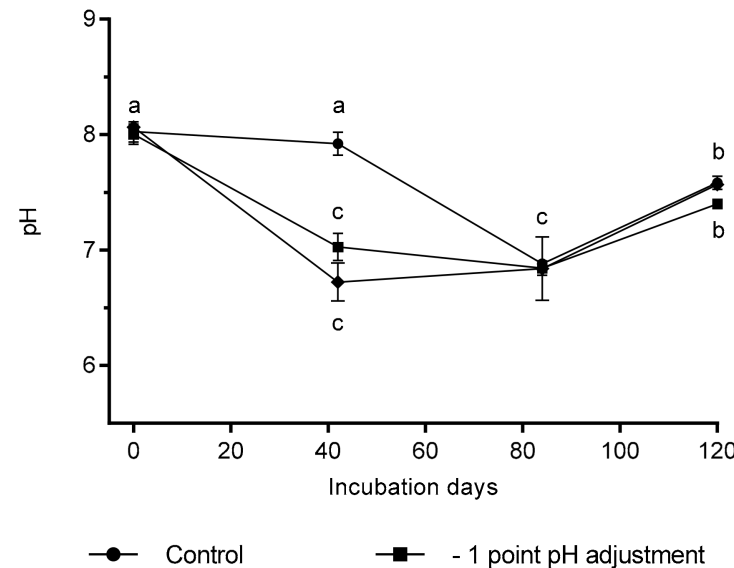

$\mathrm{pH}$ correction by elemental sulphur
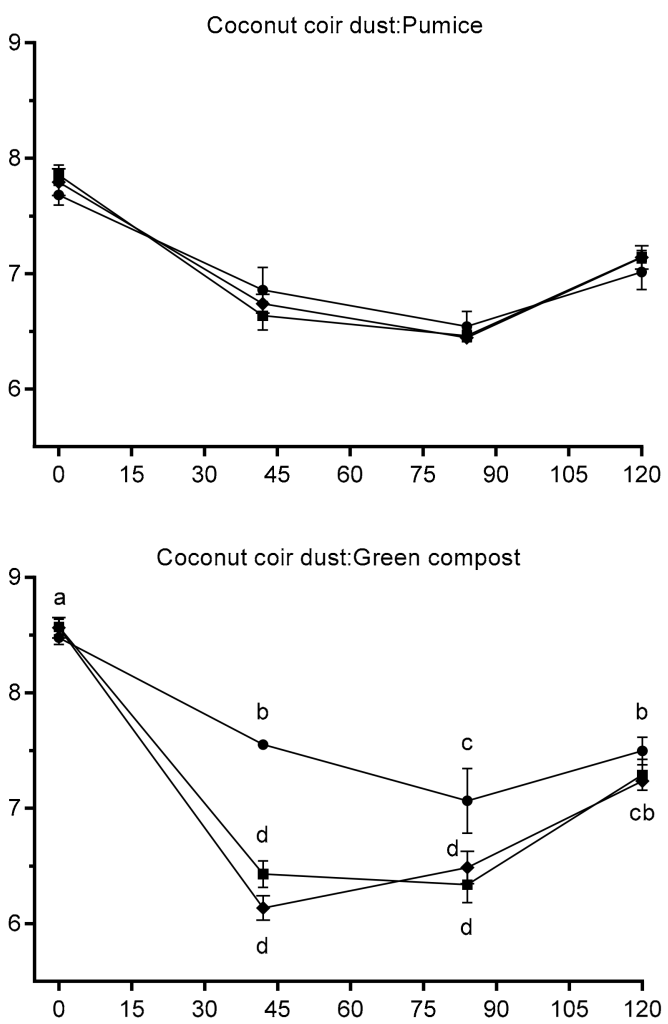

Coconut coir dust:Green compost:Stabilized wood fibre

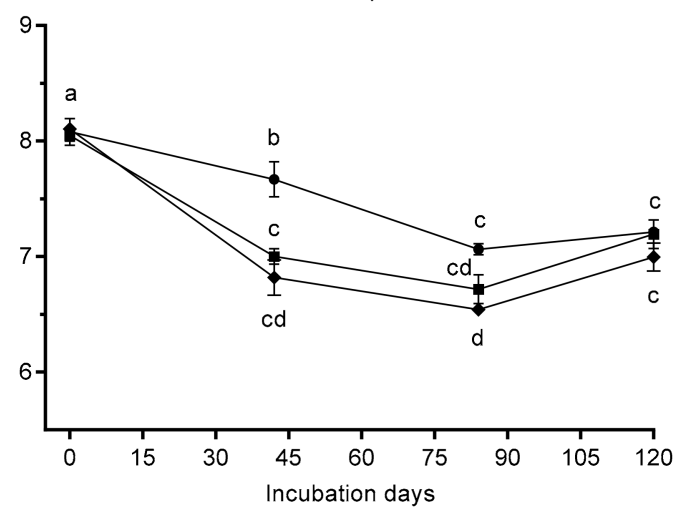

- 1.5 point $\mathrm{pH}$ adjustment

-2 point $\mathrm{pH}$ adjustment

Figure 3. Cont. 


\begin{tabular}{|c|c|c|}
\hline & $\begin{array}{c}\text { Elemental Sulphur } \\
\text { 0-120 Incubation Days }\end{array}$ & $\begin{array}{c}\text { Elemental Sulphur } \\
\text { 0-120 Incubation Days }\end{array}$ \\
\hline & Coconut coir dust & Coconut coir dust:Pumice \\
\hline $\mathrm{pH}$ & $* * *$ & n.s. \\
\hline Incubation days & $* * *$ & $* * *$ \\
\hline $\mathrm{pH} \times$ Incubation days & $* * *$ & n.s. \\
\hline $\mathrm{pH}$ & $\underset{* *}{\text { Stabilized wood fibre }}$ & $\underset{* * *}{\text { Coconut coir dust:green compost }}$ \\
\hline Incubation days & $* * *$ & $* * *$ \\
\hline $\mathrm{pH} \times$ Incubation days & $* *$ & $* * *$ \\
\hline & Green compost & $\begin{array}{l}\text { Coconut coir dust:green compost:stabilized } \\
\text { wood fibre }\end{array}$ \\
\hline $\mathrm{pH}$ & $* * *$ & $* * *$ \\
\hline Incubation days & $* * *$ & $* * *$ \\
\hline $\mathrm{pH} \times$ Incubation days & $* * *$ & $* * *$ \\
\hline
\end{tabular}

Figure 3. $\mathrm{pH}$ trend of the different matrices (coconut coir dust, stabilized wood fibre, and green compost) and of the chosen growing media during the test in field condition with elemental sulphur chips using the dosages calculated through the titration curve for lowering the $\mathrm{pH}$. $-1.5 \mathrm{pH}$ point adjustment is referred to coconut coir dust and stabilized wood fibre, while -2 point $\mathrm{pH}$ adjustment is referred to green compost and to growing media. Mean separation across time within each addition rate and across dosage at the same time was performed by two-way analysis of variance (ANOVA analysis in table: n.s., not significant; ${ }^{*} p \leq 0.05 ;{ }^{* *} p \leq 0.01{ }^{* * *} p \leq 0.001$ ). Different letters indicate significantly different values (Tukey's multiple comparisons test). Each data point is the mean of three replicates \pm standard deviation.

\section{Conclusions}

The addition of elemental sulphur chips was studied as a suitable strategy for $\mathrm{pH}$ control of coconut coir dust, stabilized wood fibre, and green compost under the experimental conditions reported in this work. An addition of elemental sulphur chips was considered a recommendable method for decreasing the $\mathrm{pH}$ about 1, 1.5, or 2 units, without increasing the electrical conductivity to levels that could reduce the agronomic value of the matrices. Instead, the addition of iron(II) sulphate did not result as acceptable, due to the quick decrease of $\mathrm{pH}$ and, at the same time, fast and higher increase of EC.

Similarly, the use of elemental sulphur chips resulted as useful also for tested growing media, especially in presence of green compost. On the other hand, sulphur chips seem to be less effective on coconut coir dust, both alone and mixed with pumice, as well as on stabilized wood fibre, especially in operative conditions, i.e., open-field trials, where the main effects were probably due to irrigation water and rain, other than their buffering capacity.

Based on the results obtained, an acidification process could be considered a useful strategy for the development of new commercial substrates, based on organic matrices other than peat, but the effects of this process on $\mathrm{pH}$ and $\mathrm{EC}$ behaviors on both plant growth and mineral nutrition of containerized crops should be further investigated.

Supplementary Materials: The following are available online at https:/ / www.mdpi.com/article / 10.3390/agronomy11050851/s1, Table S1: Chemical characteristics of the organic materials used in the trials.

Author Contributions: Conceptualization, S.D.L., D.M., S.O., and S.C.; methodology, S.D.L., D.M., and S.C.; formal analysis, S.D.L. and S.C.; data curation, S.D.L., D.M., S.O., and S.C.; writing-original draft preparation, S.D.L. and S.C.; writing-review and editing, S.D.L., D.M., S.O., and S.C.; project administration, S.C.; funding acquisition, S.C. All authors have read and agreed to the published version of the manuscript.

Funding: Trials were carried out within the SUPERA Project "SUbstrati torba-free per specie vivaistiche a elevate PErformance destinate a Recuperi ambientali e Aree verdi a bassa manutenzione", 
funding by Lombardy Region, Italy (PSR 2014/2020, Misura 16.2.01 “Progetti pilota e sviluppo di innovazione").

Data Availability Statement: The data presented in this study are available on request from the corresponding author.

Conflicts of Interest: The authors declare no conflict of interest. The funders had no role in the design of the study; in the collection, analyses, or interpretation of data; in the writing of the manuscript, or in the decision to publish the results.

\section{References}

1. Schmilewski, G. Growing Media Constituents Used in the EU in 2013. Acta Hortic. 2017, 85-92. [CrossRef]

2. Farrell, M.; Jones, D.L. Food Waste Composting: Its Use as a Peat Replacement. Waste Manag. 2010, 30, 1495-1501. [CrossRef] [PubMed]

3. Massa, D.; Malorgio, F.; Lazzereschi, S.; Carmassi, G.; Prisa, D.; Burchi, G. Evaluation of Two Green Composts for Peat Substitution in Geranium (Pelargonium Zonale L.) Cultivation: Effect on Plant Growth, Quality, Nutrition, and Photosynthesis. Sci. Hortic. 2018, 228, 213-221. [CrossRef]

4. Massa, D.; Prisa, D.; Lazzereschi, S.; Cacini, S.; Burchi, G. Heterogeneous Response of Two Bedding Plants to Peat Substitution by Two Green Composts. Hortic. Sci. 2018, 45, 164-172. [CrossRef]

5. Stewart-Wade, S.M. Efficacy of Organic Amendments Used in Containerized Plant Production: Part 1-Compost-Based Amendments. Sci. Hortic. 2020, 266, 108856. [CrossRef]

6. Stewart-Wade, S.M. Efficacy of Organic Amendments Used in Containerized Plant Production: Part 2-Non-Compost-Based Amendments. Sci. Hortic. 2020, 260, 108855. [CrossRef]

7. Di Lonardo, S.; Massa, D.; Orsenigo, S.; Zubani, L.; Rossi, G.; Fascella, G.; Cacini, S. Substitution of Peat in the Cultivation of Two Shrub Species Used for Ecological Restoration and Recovery of Degraded Green Areas. Acta Hortic. 2021, 97-102. [CrossRef]

8. Blok, C.; Wever, G. Experience with Selected Physical Methods to Characterize the Suitability of Growing Media for Plant Growth. Acta Hortic. 2008, 239-250. [CrossRef]

9. Caron, J.; Pepin, S.; Périard, Y. Physics of Growing Media in a Green Future. Acta Hortic. 2014, 309-317. [CrossRef]

10. Barrett, G.E.; Alexander, P.D.; Robinson, J.S.; Bragg, N.C. Achieving Environmentally Sustainable Growing Media for Soilless Plant Cultivation Systems-A Review. Sci. Hortic. 2016, 212, 220-234. [CrossRef]

11. Wallach, R. Chapter 3-Physical characteristics of soilless media. In Soilless Culture, 2nd ed.; Raviv, M., Lieth, J.H., Bar-Tal, A., Eds.; Elsevier: Boston, MA, USA, 2019; pp. 33-112, ISBN 978-0-444-63696-6.

12. Gruda, N.S. Increasing Sustainability of Growing Media Constituents and Stand-Alone Substrates in Soilless Culture Systems. Agronomy 2019, 9, 298. [CrossRef]

13. Fitzpatrick, G.E. Compost Utilization in Ornamental and Nursery Crop Production Systems. In Compost Utilization in Horticultural Cropping Systems; Lewis Publishers: New York, NY, USA, 2001; pp. 135-150. [CrossRef]

14. Raviv, M. Production of High-Quality Composts for Horticultural Purposes: A Mini-Review. HortTechnology 2005, 15, 52-57. [CrossRef]

15. Carrión, C.; de la Fuente, R.G.; Fornes, F.; Puchades, R.; Abad, M. Acidifying Composts from Vegetable Crop Wastes to Prepare Growing Media for Containerized Crops. Compost Sci. Util. 2008, 16, 20-29. [CrossRef]

16. Amberger-Ochsenbauer, S.; Jauch, M.; Schmitz, H.-J.; Meinken, E. Effect of Elemental Sulfur and Nitrogen Form on Substrate pH and Growth of Calibrachoa in Growing Media Containing Compost High in Carbonate. Acta Hortic. 2017, 359-364. [CrossRef]

17. Handreck, K.A.; Black, N.D.; Black, N. Growing Media for Ornamental Plants and Turf; UNSW Press: Sydney, Australia, 2002.

18. Costello, R.C.; Sullivan, D.M. Determining the pH Buffering Capacity of Compost via Titration with Dilute Sulfuric Acid. Waste Biomass Valorization 2014, 5, 505-513. [CrossRef]

19. Roig, A.; Cayuela, M.L.; Sánchez-Monedero, M.A. The Use of Elemental Sulphur as Organic Alternative to Control pH during Composting of Olive Mill Wastes. Chemosphere 2004, 57, 1099-1105. [CrossRef]

20. de la Fuente, R.G.; Carrión, C.; Botella, S.; Fornes, F.; Noguera, V.; Abad, M. Biological Oxidation of Elemental Sulphur Added to Three Composts from Different Feedstocks to Reduce Their pH for Horticultural Purposes. Bioresour. Technol. 2007, 98, 3561-3569.

21. Dias, V.; Mechant, E.; Hoekstra, B.; Perneel, M.; Vandecasteele, B. Sustainable Growing Media Based on Green Waste Compost and Other Organic Recycled Materials: Use of Elemental Sulphur to Control pH. In Proceedings of the International Symposium on Growing Media, Composting and Substrate Analysis-SusGro2015 1168, Vienna, Austria, 11 September 2015; pp. 167-174.

22. Germida, J.J.; Janzen, H.H. Factors Affecting the Oxidation of Elemental Sulfur in Soils. Fertil. Res. 1993, 35, 101-114. [CrossRef]

23. Bustamante, M.A.; Ceglie, F.G.; Aly, A.; Mihreteab, H.T.; Ciaccia, C.; Tittarelli, F. Phosphorus Availability from Rock Phosphate: Combined Effect of Green Waste Composting and Sulfur Addition. J. Environ. Manag. 2016, 182, 557-563. [CrossRef]

24. Attoe, O.J.; Olson, R.A. Factors Affecting Rate of Oxidation in Soils of Elemental Sulfur and That Added in Rock Phosphate-Sulfur Fusions. Soil Sci. 1966, 101, 317-325. [CrossRef]

25. Aulakh, M.S.; Sharma, R. Temperature Effects on Soil Organic Sulphur Mineralization and Elemental Sulphur Oxidation in Subtropical Soils of Varying pH. Nutr. Cycl. Agroecosyst. 1999, 54, 175-182. 
26. Vandecasteele, B.; Pot, S.; Maenhout, K.; Delcour, I.; Vancampenhout, K.; Debode, J. Acidification of Composts versus Woody Management Residues: Optimizing Biological and Chemical Characteristics for a Better Fit in Growing Media. J. Environ. Manag. 2021, 277, 111444. [CrossRef] [PubMed]

27. Miserez, A.; Nelissen, V.; Pauwels, E.; Schamp, B.; Grunert, O.; Van der Veken, B.; Ceusters, J.; Vancampenhout, K. Characteristics of Residues from Heathland Restauration and Management: Implications for Their Sustainable Use in Agricultural Soils or Growing Media. Waste Biomass Valorization 2019, 11, 1-18. [CrossRef]

28. Wissner, P.; Bohne, H.; Heumann, S.; Emmel, M. Plant Biomass from Heathland Management: A Possible Peat Substitute? In Proceedings of the International Symposium on Growing Media, Composting and Substrate Analysis-SusGro2015 1168, Vienna, Austria, 11 September 2015; pp. 27-32.

29. De Boodt, M.; Verdonck, O. The Physical Properties of the Substrates in Horticulture. In Proceedings of the III Symposium on Peat in Horticulture 26, Dublin, Ireland, 28 June-3 July 1971; pp. 37-44.

30. Harada, Y.; Inoko, A. The Measurement of the Cation-Exchange Capacity of Composts for the Estimation of the Degree of Maturity. Soil Sci. Plant Nutr. 1980, 26, 127-134. [CrossRef]

31. Bunt, B.R. Media and Mixes for Container-Grown Plants: A Manual on the Preparation and Use of Growing Media for Pot Plants; Springer Science \& Business Media, Springer Nature: Cham, Switzerland, 2012.

32. Martinez, F.X.; Casasayas, R.; Burés, S.; Cañameras, N. Titration Curves of Different Organic Substrates. In Proceedings of the Symposium on Horticultural Substrates and their Analysis 221, Gl. Avernaes, Funen, Denmark, 5-11 September 1987; pp. 105-116.

33. Taylor, M.D.; Kreis, R.; Rejtö, L. Establishing Growing Substrate pH with Compost and Limestone and the Impact on pH Buffering Capacity. HortScience 2016, 51, 1153-1158. [CrossRef]

34. Costello, R.C.; Sullivan, D.M.; Bryla, D.R.; Strik, B.C.; Owen, J.S. Compost Feedstock and Compost Acidification Affect Growth and Mineral Nutrition in Northern Highbush Blueberry. HortScience 2019, 54, 1067-1076. [CrossRef]

35. Marfà, O.; Tort, J.M.; Olivella, C.; Cáceres, R.; Martínez, F.X. Cattle Manure Compost as Substrate. II-Conditioning and Formulation of Growing Media for Cut Flower Cultures. In Proceedings of the International Symposium on Composting \& Use of Composted Material in Horticulture 469, Scotland, UK, 5-11 April 1997; pp. 305-312.

36. Abad, M.; Noguera, P.; Bures, S. National Inventory of Organic Wastes for Use as Growing Media for Ornamental Potted Plant Production: Case Study in Spain. Bioresour. Technol. 2001, 77, 197-200. [CrossRef]

37. Carlile, W.R.; Cattivello, C.; Zaccheo, P. Organic Growing Media: Constituents and Properties. Vadose Zone J. 2015, 14, 1-13. [CrossRef]

38. Carlile, W.R.; Raviv, M.; Prasad, M. Chapter 8-Organic Soilless Media Components. In Soilless Culture, 2nd ed.; Raviv, M., Lieth, J.H., Bar-Tal, A., Eds.; Elsevier: Boston, MA, USA, 2019; pp. 303-378, ISBN 978-0-444-63696-6.

39. Van Gerrewey, T.; Ameloot, N.; Navarrete, O.; Vandecruys, M.; Perneel, M.; Boon, N.; Geelen, D. Microbial Activity in PeatReduced Plant Growing Media: Identifying Influential Growing Medium Constituents and Physicochemical Properties Using Fractional Factorial Design of Experiments. J. Clean. Prod. 2020, 256, 120323. [CrossRef]

40. Mari, I.; Ehaliotis, C.; Kotsou, M.; Chatzipavlidis, I.; Georgakakis, D. Use of Sulfur to Control pH in Composts Derived from Olive Processing By-Products. Compost Sci. Util. 2005, 13, 281-287. [CrossRef] 